\title{
Factors Affecting Equity Return during Corporate Declaration
}

\author{
Nasima Khatun \\ Lecturer, Department of Business Administration, East West University, Dhaka, Bangladesh \\ Dipa Rani Saha \\ BBA \& MBA(Marketing), Faculty of Business Studies, University of Dhaka, Bangladesh
}

\begin{abstract}
In an efficient market, stock prices would be determined primarily by some fundamental factors. This study aims at finding the impact of some factors on the equity prices. The main target of this study is to explain the price return of shares listed in Dhaka Stock Exchange (DSE), Bangladesh. We ran regression analysis with the help of panel data and find out the relationship between dependent and all the independent variables used in the study. We examined the regressions over the four years and identified the relative changes in the impact of independent variables.
\end{abstract}

Keywords: DSE, Equity return, Earnings Surprise, Market Momentum

DOI: $10.7176 /$ RJFA/10-16-05

Publication date: August $31^{\text {st }} 2019$

\section{Introduction}

\subsection{Background of the Study}

Bangladesh is finally going to be recognized as a least developed country. The country is being considered the potential economic power in the world economic area. The strength of the economy is reflected through the performance of stock market. After facing crisis in different phases of time, the stock market is going to be settled in a moderate speed. The basic notion underlying the security market is that the movement in the security market affects all the security. The fundamental observation of share price indicates that when market moves up, price of most of the shares moves up and vice-versa. However, a change occurs in the price of a stock only because of certain changes in the economy, industry or company. Any sorts of information about the changes influence the stock prices immediately and the stock moves to new level depending upon the level and magnitude of the information.

This study focuses on the price return of individual stocks during the period of the corporate declaration. Time horizon of this study is four years. The study aims at finding out the impact of company and economy specific variables in the price return. That is why this study selects some variables and find out the impact of those selected variables on the price return. It also focuses on whether the impact of those selected variables is decreased or increased over these four years.

\subsection{Objective of the Study}

The objectives of the study are:

I. To test the impact of variables on price return

II. To find out the trend in the impact of those variables during the study period

III. To test whether all the independent variables are individually significant or not

IV. To test the significance of total equation

\subsection{Methodology}

The study is about an event study. The aim of the study is to find out the impact of some factors on the price return during the period of corporate declaration. We have focused on almost all the companies listed in DSE based on some crucial criteria for analyzing the ultimate price return.

Basically, movement of any stock's price begins when the date of annual general meeting is declared or some days before that declaration. The total impact of the declaration is adjusted on the first trading day after declaration. That is why, this study tries to explain price return of the security and the time period of this return calculation ranges from the first trading day after declaration and five trading day before the declaration. Five factors are selected as our independent variables and they are-earnings surprise, earnings change, dividend change, stock dividend, market momentum. Our research horizon is five years and it is based on listed companies of DSE. To do so, data is primarily collected from the website of DSE and Stock Bangladesh Limited. Currently, more than five hundred and seventy companies are listed in Dhaka Stock Exchange. But we reduce our sample size based on some criteria. The criteria are

I. The company must not be listed after 2012.

II. The company must have declared dividend in the year of 2014 to 2017 
III. The company must not have any net loss in yearly basis for the fiscal period of 2014, 2015, 2016 and 2017.

There are some reasons for the above criteria. If the company is not listed within 2012, we will not get net income for 2013 and we will be unable to calculate the earnings surprise for 2014. Finally, if the company does not pay any dividend in any year from 2014 to 2017, we will not get the price return (our independent variable) during the corporate declaration as well as our dividend change cannot be calculated, and our regression may be invalid.

\subsection{Scope of the Study}

The scope of the study is limited to the following situation:

I. Closing Price of the securities is considered for calculating price return

II. Time period covered is 2014-2017.

III. Sample Size is 612 firm year observations.

\section{Literature Review}

Capital Market is one of the indicators of a country's economy. The condition of the capital market depicts relative position of the economy. Bundles of studies have been conducted on the issues concerning the capital market.

P.S. Nirmala, P.S. Sanju and M. Ramchandran (2011) in their study named "Determinants of Share Prices in India" mentioned some determinants that have a direct impact on share prices. Among them, they specially focus on dividend effect and bonus share effect. According to them, dividend and bonus share effect create a positive effect on investor's mind. This effect motivates the investors to create upward pressure on the share price.

Dr. Mahmood Osman Imam and Mahfuja Malik (2007) in their study named "Firm Performance and Corporate Governance through Ownership Structure: Evidence from Bangladesh Stock Market" described about the impact of market momentum on the prices of securities. They said that the movement of the stock market affects all the security. The fundamental observation of share price indicates that when market moves up, price of most of the shares moves up and vice-versa.

The aim of this study is the impact of factors in the prices of equity securities. Keeping the objectives in mind of the present study, we had reviewed the existing literatures: The Capital Market Development in Bangladesh: problems and prospects (Mahmood Osman Imam, October 5, 2000), An Application of Variance-Ratio Test of Five Asian Stock Markets (M. Imam Alam, Tanweer Hasan and Palani-Rajan Kadapakkam,1999). Daily Market Review by Lanka Bangla Securities Limited and Financial Markets and Institutions (Jeff Madura, 2008) are also reviewed for this study.

However, although these studies offered various insights into the dynamics of the current capital market of Bangladesh, their extent of point of discussion are different and reviewed from different aspects. In this paper, we have tried to compile and explain all the relevant information to make the paper successful.

\section{Overview of the Dhaka Stock Exchange \\ 3.1 Definition of Capital Market}

Capital market can be termed as the engine of raising capital, which accelerates industrialization and the process of privatization. In other words, capital market means the share and stock markets of the country. It is a market for long-term fund. With the emergence of the need for infrastructural development projects, for setting up of new industries for entrepreneurial attempts, more funds are needed.

\subsection{Function of Capital Market}

The functioning of an efficient capital market may ensure smooth floatation of funds from the savers to the investors. When banking system fails to provide sufficient funds for the economy, capital market then works as a helping hand. To put it in a single sentence, we can therefore say that the increased need for funds in the business sector has created an immense need for an effective and efficient capital market. It facilitates an efficient transfer of resources from savers to investors and becomes conduits for channeling investment funds from investors to borrowers. The capital market is required to meet at least two basic requirements:

$\checkmark$ It should support industrialization through savings mobilization, investment fund allocation and maturity transformation and

$\checkmark \quad$ it must be safe and efficient in executing above-mentioned function

\subsection{History of Dhaka Stock Exchange}

Dhaka Stock Exchange, the main stock exchange of Bangladesh, is still at its infant stage. On April 28, 1954, DSE was first incorporated as the East Pakistan Stock Exchange Association Limited. However, formal trading began in 1956 with 196 securities listed in the DSE with a total paid-up capital of about 4 billion. On June 23, 
1962, it was renamed as Dhaka Stock Exchange Limited. After 1971, the trading activities of the stock exchange remained suppressed until 1976 due to the liberation war. The trading activities resumed in 1976 with only nine companies listed having a paid-up capital of Taka137.52 million. Currently, different types of securities, bonds, debentures and mutual funds are traded in DSE. The market is now much bigger than what it was in its inception. In accordance with fiscal year 2017-2018, total market capitalization was 38,47,348(BDT billion) and total number of securities was 572 .

\subsection{Classification of Companies}

All the companies listed in Dhaka Stock Exchange are classified into four categories namely "A, B, N and Z". Some characteristics regarding those categorizations are given below:

A category Companies

Companies, which are regular in holding the Annual General Meetings (AGM) and have declared dividend at the rate of 10 percent or more in a calendar year.

B category Companies

Companies, which are regular in holding the Annual General Meetings (AGM) but have failed to declare dividend at least at the rate of 10 percent in a calendar year.

N category Companies

All newly listed companies who have not held any Annual General Meeting (AGM).

$\underline{Z}$ category Companies

Companies which have failed to hold the Annual General Meetings (AGM) or failed to declare any dividend or which are not in operation continuously for more than six months or whose accumulated loss after adjustment of revenue reserve, if any is negative and exceeded its paid-up capital.

\section{Analysis of Selected Variables}

The study deals with some variables that have an impact on the return of equities. Basically, price return is the dependent variable. To explain the independent variable, we have selected five independent variables. All the dependent and independent variables are described below:

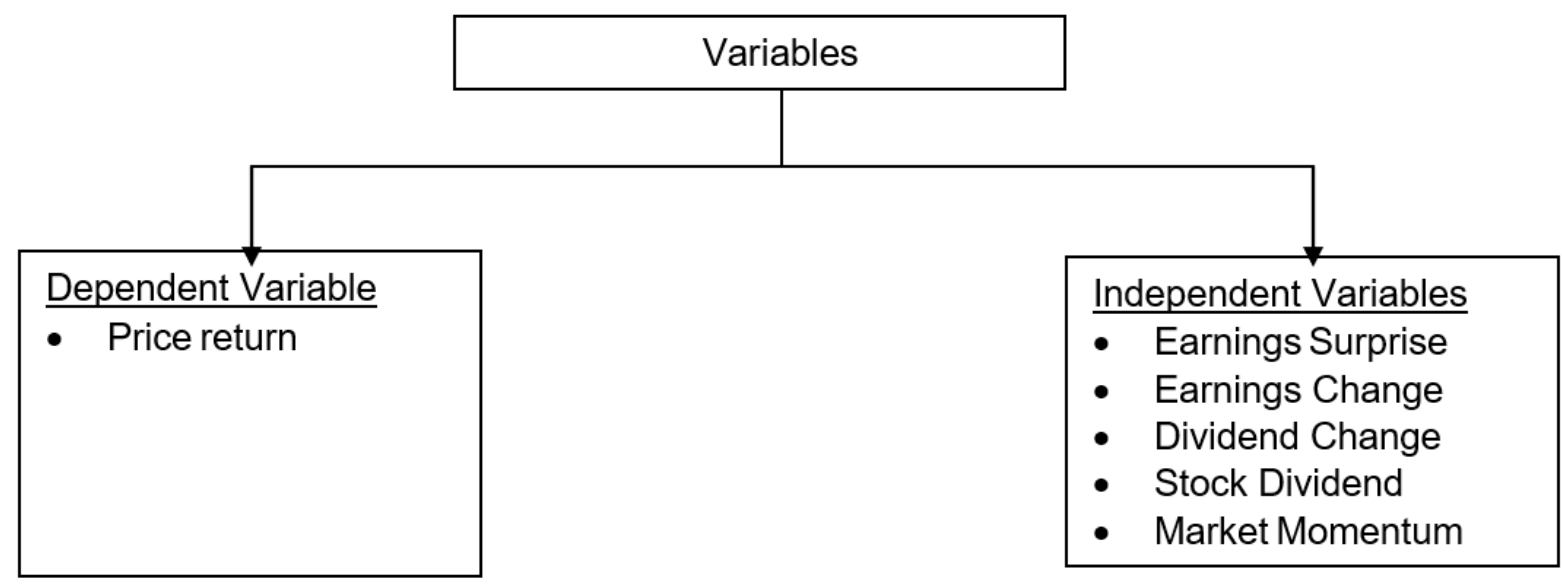

\subsection{Price Return}

Price return is considered as our dependent variable. The price return is the rate of return on an investment portfolio, where the return considers only the capital appreciation of the portfolio. The time duration for calculating price return is the first trading day after declaration and fifth day before the dividend declaration. Closing price of those two specific days is taken as input. Our target is to find out whether the independent variables force to move it in the positive side or negative side. The following formula is used to calculate price return:

Price return $=\frac{\text { Closing Price }_{t}-\text { Closing Price }_{t-5}}{\text { Closing Price }_{t-5}}$

Here, $\mathrm{t}=$ First trading day after Dividend Declaration

\subsection{Earnings Surprise}

Earnings surprise means the extra earnings, which is not expected by the outsiders of the company. In other 
words, earnings surprise means company's reported quarterly or annual profits which are above or below analysts' expectations. Earnings surprise has a positive relationship with the price return. When a company declares a good earnings surprise, investors are willing to pay good price for the shares of the company and ultimately lead to a positive price return or vice versa. The outsiders of the company, mainly investors and analysts forecast earnings based on the earnings of the third quarter. This method is also maintained here. The following formula is used to calculate earnings surprise:

\section{Actual Yearly Earnings - Earnings Annualized Earnings Annualized}

Here, Actual Yearly Earnings = Audited Earnings

Earnings Annualized $=($ Third Quarter Earnings $/ 3) * 4$

\subsection{Earnings Change}

Earnings is the portion of a company's profit that is allocated to each outstanding share of common stocks. It is an indicator representing company's financial health. Investors typically compare the earnings with other companies within the same industry to get a sense of how the company is performing. Earnings change allows the investoranalyst to understand the change in profitability relative to the prior earnings period. We calculated earnings change in earnings per share by prior period earnings per share. It is the way to understand if the company is growing its earnings. Like earnings surprise, investors are particularly interested in earnings and it has a positive relationship with price change. The following formula has been applied for calculating earnings change:

$$
\text { Earnings Change }=\frac{\text { Total Earnings }_{n}-\text { Total Earnings }_{n-1}}{\text { Total Earnings }_{n-1}}
$$

Here, $\mathrm{n}=$ Current Year

\subsection{Dividend change}

Dividend is the portion of the earnings that is paid to the equity holders. Dividend is generally paid to the equity holders in two forms. One is cash dividend, and another is stock dividend. In our study, for calculating dividend change, cash dividend is considered. Dividend decision is based on two factors. One is company's annual profit, and another is average pay-out ratio. Based on these two factors, analysts have a dividend forecast. Sometimes, a company has some unusual earnings or changes its historical pay-out ratio and ultimately leads to a dividend surprise. Dividend surprise has a positive relationship with the price return. If a company declares dividend higher than last year it means that investors will get some extra income and they will be willing to pay some extra price. The following formula is used to measure dividend surprise:

Dividend Change $=\frac{\text { Total Dividend } \mathrm{d}_{n}-\text { Total Dividend }_{n-1}}{\text { Total Dividend }}$

Here, $\mathrm{n}=$ Current Year

\subsection{Stock dividend}

Stock dividend is also known as bonus share. A bonus share is a free share of stock given to current shareholders in a company, based upon the number of shares that the shareholder already owns. While the issue of bonus shares increases the total number of shares issued and owned, it does not change the value of the company. Although the total number of issued shares increases, the ratio of number of shares held by each shareholder remains constant. Bonus share has a positive impact on shareholder's mind. When a company declares bonus share, investors want to hold or buy the shares and ultimately increases the price. In this study, a qualitative process is used to measure this effect. We assume that if a company has a good history of declaring dividend, investors possess good impression on this company. We create here two groups. If a company pays stock dividend minimum three years within the last five years, it is considered as a stock dividend paying company and viceversa.

\subsection{Market Momentum}

Market momentum means the movement of the market or the overall market sentiment. In our study, market momentum is considered during the declaration period of the securities. Market movement gives a broad idea of what the mass investors are thinking about the market. Whether the mass investors are positive about the market or not is understood by the market movement. This measure also shows the relative bullishness and bearishness 
of the market. Market movement has a positive impact on the price return. General index of DSE namely "DGEN" is used to measure market momentum.

Market Momentum $=\frac{\text { DGEN }_{t}-\text { DGEN }_{t-7}}{\operatorname{DGEN}_{t-7}}$

Here, DGEN $=$ General Index of Dhaka Stock Index

$\mathrm{t}=$ First trading day after Dividend Declaration

\section{Regression Analysis}

The main aim of this study is to do a regression analysis and find out the relationship between dependent and all the independent variables. Our aim is not only confined to that we also test whether the independent variables are significant or not. We run the regression with panel data over the four-year horizons and find out the relative changes in the impact of independent variables.

\subsection{Regression Analysis}

As mentioned above, our regression equation is a combination of five independent variables and one dependent variable. To create regression equation, we mainly focus on dividend declaration date. That means whether the fiscal year ended on 31 December 2013 or any date in 2014 is not our focus. Dividend should be declared in 2014. The regression equation for our panel data is below:

$\mathrm{Y}=-0.03832+0.00392 \mathrm{X}_{1}+0.00033119 \mathrm{X}_{2}+0.02482 \mathrm{X}_{3}+0.0464 \mathrm{X}_{4}+1.22958 \mathrm{X}_{5}$

Here,

$$
\begin{array}{ll}
\mathrm{Y} & =\text { Price return } \\
\mathrm{X}_{1} & =\text { Earnings Surprise } \\
\mathrm{X}_{2} & =\text { Earnings Change } \\
\mathrm{X}_{3} & =\text { Dividend Change } \\
\mathrm{X}_{4} & =\text { Stock Dividend } \\
\mathrm{X}_{5} & =\text { Market Momentum }
\end{array}
$$

Here, we find that all the independent variables have positive relationships with the price return. That means if dividend and earnings surprise are positive and market moves positively, it will create an upward pressure in the stock price and ultimately leads to positive price return.

Now, our target is to determine whether all these independent variables are individually statistically significant or not. In short, individually whether they have any impact or not. To do so, we assume that

$\mathrm{H}_{0}$ : Independent variables have no impact on the dependent variable.

$\mathrm{H}_{1}$ : Independent variables have impact on the dependent variable.

To test the hypothesis, we use "P" values. At 5\% level of confidence, the result is given below:

\begin{tabular}{|l|c|c|}
\hline \multicolumn{1}{|c|}{ Variable } & t Value & $\mathbf{P}>|\mathbf{t}|$ \\
\hline Intercept & -6.98 & $<.0001$ \\
\hline Earnings Surprise & 2.46 & 0.014 \\
\hline Earnings Change & 1.62 & 0.1065 \\
\hline Dividend Change & 4.27 & $<.0001$ \\
\hline Stock Dividend & 6.22 & $<.0001$ \\
\hline Market Momentum & 5.88 & $<.0001$ \\
\hline
\end{tabular}

We know that "P" value measures the minimum level of significance at which the null hypothesis can be rejected. Our significance level is $5 \%$. From the table, it is found that earnings surprise, dividend change, stock dividend and market momentum have a "P - value" less than 5\%.That means at 5\% level of significance, we can reject the null hypothesis and accept the alternate hypothesis for these four variables. From the table above, it can be said that all the independent variables except earnings change are statistically significant. That means all the independent variables earnings change have impact on the dependent variable.

\begin{tabular}{|l|l|c|c|c|c|}
\hline Variable & $\mathbf{N}$ & Mean & Std Dev & Minimum & Maximum \\
\hline Price Return & 692 & $(0.02)$ & 0.10 & $(0.42)$ & 0.64 \\
\hline Earnings Surprise & 752 & 0.08 & 2.73 & $(38.88)$ & 40.33 \\
\hline Earnings Change & 612 & 3.47 & 17.93 & $(96.33)$ & 229.80 \\
\hline Dividend Change & 655 & $(0.14)$ & 0.68 & $(1.35)$ & 8.00 \\
\hline Stock Dividend & 819 & 0.44 & 0.50 & - & 1.00 \\
\hline Market Momentum & 694 & $(0.01)$ & 0.02 & $(0.06)$ & 0.08 \\
\hline
\end{tabular}




\section{Findings of the Study}

From the statistical analysis, we can say that more or less all the results are satisfactory. Furthermore, some findings are clearly eminent, and they are described below:

$>$ We know that earnings surprise attracts investors. If any investors are unable to get abnormal profit from earnings surprise, market is considered as semi-strong form of efficient. In our analysis, earnings surprise is statistically significant, its co-efficient is 0.00392 which means that holding everything else constant, for 1 percent change in earning surprise, price return will be increased by 0.39 percent. This can lead to the conclusion that market is not semi-strong form of efficient.

Like earnings surprise, dividend change attracts all the investors to those specific shares. This study also finds that dividend change is positively related with the price return. Co-efficient of dividend change reflects almost $2.5 \%$ change in price return.

$>$ When bonus share is declared, it means free share of stock given to current shareholders in a company. Even though, in the long run, bonus share reduces the ability of the firm to maintain consistent dividend policy by increasing the paid-up but it has a positive impact for the investors. In our study, this variable is significant.

$>$ Market momentum is an indicator which depicts the overall movement of the market. In our study we find that market momentum is statistically significant and positively related with the independent variable. Co-efficient of this variable is more than one which means that one percent change in market will positively affect price return more than one percent. Moreover, it can be said that market on an average has a good impact on the price movement.

$>$ Earnings change does not have any significant effect in the price return during the corporate declaration. The result tells that investors keep close track in the change in the earnings. In other words, investors fully reflect the information of earnings change in the price. As a result, it does not have any significant impact in the price during the corporate declaration.

\section{Conclusion}

Capital market is one of the indicators of any country's economy. It shows the relative condition of the economy whether it is in recession or in peak. Capital market is basically classified into primary market and secondary market. After the initial offering, securities are traded in the secondary market among the investors. Prices in the secondary market can be affected by the several factors. There are also some regulatory factors which influence security prices. Except them, dividend surprise and market momentum are very influential factors. In the study, both these factors are found statistically significant and have positive relationship with the security prices. Market momentum has a co-efficient of more than 1. Earnings surprise is also statistically significant and has a positive relation but its co-efficient declines over time. This can lead to the conclusion that market is moving toward semi-strong form of efficiency. Bonus share does not have any clear impact as it is not beneficial for the investors in the long run. In fine, investors should be aware of these facts.

\section{References}

P.S. Nirmala, P.S. Sanju and M. Ramchandran, 2011, Determinants of share prices in India, Journal of Emerging Trends in Economics and Management Sciences, Volume 2, Issue 2, Apr 2011, p. 124 - 130

Mahmood Osman Imam and Mahfuja Malik, 2007, Firm Performance and Corporate Governance through Ownership Structure: Evidence from Bangladesh Stock Market, International Review of Business Research Paper, vol.3, No.4, pp.88-110

M. Imam Alam, Tanweer Hasan and Palani-Rajan Kadapakkam,1999, An Application of Variance-Ratio Test of Five Asian Stock Markets, Review of Pacific Basin Financial Markets and Policies, Vol.02, No.03, pp.301315

Financial Markets and Institutions, Jeff Madura, 2008

Daily Market Review, Lanka Bangla Securities Limited, Bangladesh

Dhaka Stock Exchange, https://www.dsebd.org/

Stock Bangladesh Limited, https://stockbangladesh.mobi/index-normal.php?alp=all 